\title{
Serum Alpha-fetoprotein in Rabbits Experimentally Infected with Rabbit Haemorrhagic Disease Virus
}

\author{
Sheng-Yi Chen, Jui-Hung Shien, Hong Kean Ooi \\ Department of Veterinary Medicine, National Chung Hsing University, Taichung city, Taiwan, Republic of \\ China (R.O.C.) \\ Received January 24, 2008 \\ Accepted May 18, 2009
}

\begin{abstract}
To investigate the change in serum alpha-fetoprotein (AFP) and its correlation with liver enzymes in hepatitis caused by rabbit haemorrhagic disease virus (RHDV), 15-week-old rabbits were experimentally infected with a Taiwan field isolate of the virus. After RHDV inoculation, it was observed that serum AFP increased significantly $(p=0.0082)$ together with significant elevation in serum aspartate amino transferase (AST), alanine amino transferase (ALT), $\gamma$-glutamyl transferase $(\gamma-G T)$ and alkaline phosphatase (ALP). Rabbits that died tended to have high AFP values prior to death, the mean value being $4.22 \pm 1.61 \mathrm{ng} / \mathrm{ml}(\mathrm{n}=6)$. By correlation analysis, AFP significantly correlated more strongly to ALP than $\gamma$-GT, but non-significantly with AST and ALT. This is the first report of serum AFP elevation being associated with RHDV infection. Thus, measurement of serum AFP might be a useful complementary index for RHDV infectivity and prognosis.
\end{abstract}

Alpha-fetoprotein, rabbit haemorrhagic disease, serum enzymes

Rabbit haemorrhagic disease (RHD) has been designated by the World Organization for Animal Health (OIE) as a notifiable disease in lagomorphs. It was first recognized in China in 1984 (Liu et al. 1984) and soon spread worldwide. It became important in the international trade of rabbits and its products. The RHD virus (RHDV), a member of Caliciviridae, is a single strand, non-enveloped, positive-sense RNA virus with VP60 (60 kDa in size) as its major structural protein (Ohlinger et al. 1990). RHDV infection has been characterized as acute fatal necrotic viral hepatitis in both wild and domestic adult rabbit (Cooke et al. 2000), whereas younger rabbits usually survive and become RHD virus (RHDV) carriers (Xu and Chen 1989). The lesions and the progression of the disease in adult rabbits were similar to those presented in human fulminant hepatitis (Tunon et al. 2003). Hence, study on RHD not only benefit rabbit industry but could also contribute to the understanding of human viral hepatitis.

Alpha-fetoprotein (AFP) is known to increase in tissues and in circulation under various inflammatory conditions. Hepatitis is one of the few non-neoplastic disorders known to cause an increase in AFP (Kumar et al. 2005). AFP elevation was recorded in $45.6 \%$ of 432 hepatitis B surface antigen-positive patients (Liaw et al. 1986). However, the elevation of AFP in RHD has not been studied. In this study, we experimentally infected New Zealand White rabbits with RHDV to investigate the kinetics of AFP and its correlation with serum liver enzymes.

\begin{abstract}
Materials and Methods
Animals

Eight 15-week-old, clinically healthy New Zealand White rabbits, 4 males and 4 females, were purchased from the National Animal Health Research Institute in Taiwan. The rabbits were separated by sex and kept isolated from the other rabbits in sanitized wired cages. All were fed commercial dry rabbit feed (Fwu-Sow Industry CO., Taichung, Taiwan) containing $19 \%$ crude protein, $10 \%$ crude fibre and $2500 \mathrm{kcal} / \mathrm{kg}$. None of the rabbits were previously vaccinated with RHD-killed vaccine. The rabbits were kept and handled according
\end{abstract}

Address for correspondence:

Hong Kean Ooi

Department of Veterinary Medicine, National Chung Hsing University,

250 Kuo-Kuang Rd., Taichung, 40227, Taiwan

Republic of China (R.O.C.)
Phone: $+886-4-22840206$ ext. 11 or $886-927541035$

Fax:+886-4-22856782

E-mail: hkooi@mail.nchu.edu.tw

http://www.vfu.cz/acta-vet/actavet.htm 
to the regulations laid down by the Institutional Animal Care and Use Committee (IACUC) of National Chung Hsing University.

Virus

The RHDV was isolated from homogenized liver specimens of a field case. A $10 \%$ suspension of the homogenized liver was made in $0.01 \mathrm{M}$ phosphate-buffered saline followed by centrifugation at $7000 \times \mathrm{g}$ for $30 \mathrm{~min}$ at $4{ }^{\circ} \mathrm{C}$. The supernatant was then filtered through $0.22 \mu \mathrm{m}$ filter and stored at $-70{ }^{\circ} \mathrm{C}$ until used. After titration, the experimental rabbits were intramuscularly inoculated each with $0.5 \mathrm{ml}$ RLD50 (50\% Rabbit lethal dose) of RHDV. Details of the procedure have been reported by Shien et al. (1998).

Blood sample collection

About $1.5 \mathrm{ml}$ of blood from auricular vein was obtained from the rabbits after $8 \mathrm{~h}$ of fasting as baseline. After virus inoculation, blood samples were collected from $18 \mathrm{~h}$ post inoculation (HPI) and every $6 \mathrm{~h}$ until 48 HPI or terminated if the animal died during the course of infection. Blood samples were collected in syringes without anticoagulant, left at room temperature for $30 \mathrm{~min}$ and then at $4{ }^{\circ} \mathrm{C}$ for $30 \mathrm{~min}$ for serum elution. The sera were then centrifuged at $1000 \times \mathrm{g}$ for $10 \mathrm{~min}$ and the supernatant used for biochemistry tests.

Measurement of alpha-fetoprotein

Serum AFP was measured by quantitative sandwich immunoassay using a commercial kit (Fujirebio Taiwan Inc., Taiwan). Briefly, positive as well as negative standards and RHDV infected rabbit sera were added into microtitre plates which were pre-coated with a monoclonal antibody (MoAb) specific for human AFP. After 30 -min incubation at $37{ }^{\circ} \mathrm{C}$, the plates were washed with wash buffer and $100 \mu$ AFP MoAb conjugated with horseradish peroxidase was added into each well. The wells were reacted for $30 \mathrm{~min}$ at $37^{\circ} \mathrm{C}$, followed by washing with wash buffer. Then, $100 \mu 1$ substrate solution (3',3',5,5' tetramethylbenzidine, TMB) with H2O2 was added into each well and incubated for 10 minutes at $37^{\circ} \mathrm{C}$, followed by adding of $100 \mu$ stop solution (1N $\mathrm{HCl}$ ) and gentle mixing for $30 \mathrm{~s}$. The plates were read with an ELISA reader (model 960, Sigma CO. USA) set at an optical density (O. D.) of $450 \mathrm{~nm}$.

Serum enzymatic tests

Aspartate amino transferase (AST, EC 2.6.1.1), alanine amino transferase (ALT, EC 2.6.1.2), $\gamma$-glutamyl transferase ( $\gamma$-GT, EC 2.3.2.2), and alkaline phosphatase (ALP, EC 3.1.3.1) in the rabbit sera were measured with an autoanalyzer (model 7150, Hitachi CO., Japan) using the spectrophotometric method.

Data analysis

Data were analyzed by Statistic Analysis System (SAS 9.1). The means and standard deviations were calculated by Means Procedure on time. Least squares means of General Linear Model (GLM) procedure were applied for the analysis of the differences on the effect of time and sex. P values less than 0.05 were considered significant. The strength of the relationship that exists between the indicators was defined by the statistics of the Pearson correlation coefficient (r) and its significance by Correlation Procedure. For interpreting the strength of correlation, R squared, which can be interpreted as the proportion of variation in the variables, were applied for the strength of correlation.

\section{Results}

Six rabbits died between 27 and 37 HPI. The remaining 2 rabbits were sacrificed at 60 HPI. All rabbits showed typical RHD signs of haemorrhages in the respiratory system, liver, spleen and cardiac muscle. Hepatic necroses were seen histopathologically in all liver specimens.

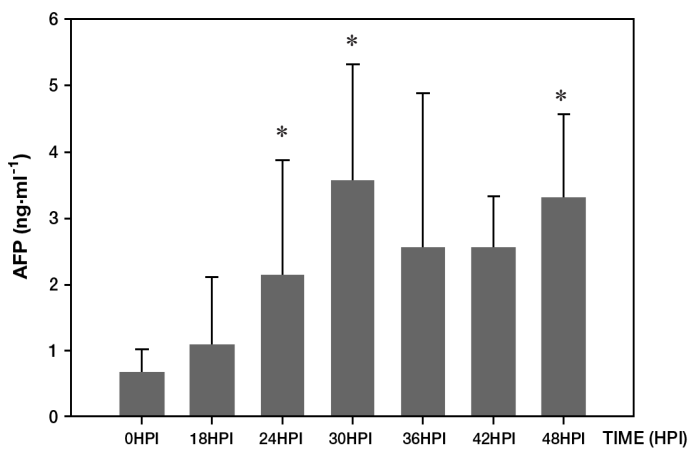

Fig. 1A. Change in AFP, $\mathrm{P}=0.0082, \mathrm{n}=8$ at $0 \mathrm{HPI}, 18 \mathrm{HPI}$ and $24 \mathrm{HPI}, \mathrm{n}=6$ at $30 \mathrm{HPI}, \mathrm{n}=2$ at $36 \mathrm{HPI}, 42 \mathrm{HPI}$ and $48 \mathrm{HPI}$
Change in AFP

AFP in the infected rabbits elevated significantly $(p=0.0082)$ as compared to the baseline values. Significant change could be observed from 24 HPI (Fig. 1A). Frequency distribution revealed an increasing right shift in that most of the AFP values at $18 \mathrm{HPI}$ and before were $\leq 1.2 \mathrm{ng} / \mathrm{ml}$ (normal value in this study), while at $24 \mathrm{HPI}, 62.5 \%$ of the AFP values were $>1.2 \mathrm{ng} / \mathrm{ml}$ (Table 1). Rabbits that died tended to have high AFP values prior to death, the mean value being $4.22 \pm 1.61 \mathrm{ng} / \mathrm{ml}(\mathrm{n}=6)$. 
Table 1. The frequency distribution in AFP value $>1.2 \mathrm{ng} / \mathrm{ml}$ in RHDV infection

\begin{tabular}{|c|c|c|c|}
\hline Time & $\mathrm{N}$ & Value $>1.2 \mathrm{ng} / \mathrm{ml}$ & $\%$ \\
\hline $0 \mathrm{~h}$ & 8 & 0 & 0 \\
\hline $18 \mathrm{~h}$ & 8 & 3 & 37.5 \\
\hline $24 \mathrm{~h}$ & 8 & 5 & 62.5 \\
\hline $30 \mathrm{~h}$ & 6 & 5 & 83.3 \\
\hline $36 \mathrm{~h}$ & 2 & 1 & 50 \\
\hline $42 \mathrm{~h}$ & 2 & 2 & 100 \\
\hline $48 \mathrm{~h}$ & 2 & 2 & 100 \\
\hline
\end{tabular}

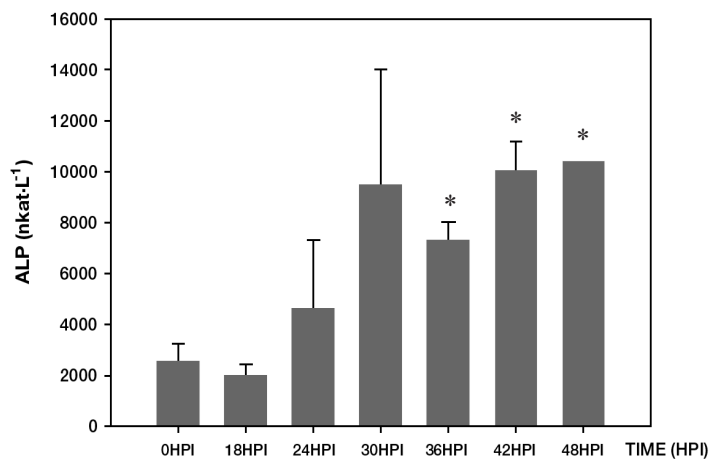

Fig. 1B. Change in ALP, $P<0.0001, \mathrm{n}=8$ at 0 HPI, 18HPI and $24 \mathrm{HPI}, \mathrm{n}=6$ at $30 \mathrm{HPI}, \mathrm{n}=2$ at $36 \mathrm{HPI}$ and $42 \mathrm{HPI}, \mathrm{n}=1$

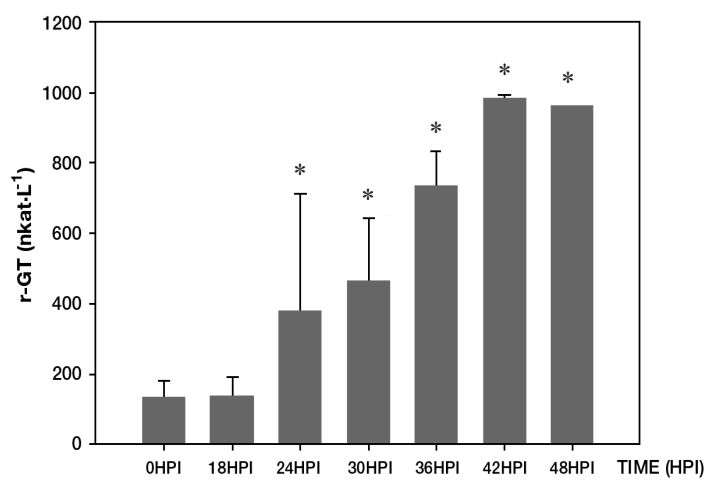

Fig. 1C. Change in $\gamma$-GT, $P<0.0001, \mathrm{n}=8$ at 0HPI, 18HPI and 24HPI, $n=6$ at $30 \mathrm{HPI}, \mathrm{n}=2$ at $36 \mathrm{HPI}$ and $42 \mathrm{HPI}, \mathrm{n}=1$ at $48 \mathrm{HPI}$$$
\text { conjugated monoclonal antibody specific for human }
$$

Changes in ALP and $\gamma$-GT

ALP and $\gamma$-GT were both elevated $(p<0.0001)$ (Fig. 1B and 1C). Significant elevations (versus baseline value) at $24 \mathrm{HPI}$ and $36 \mathrm{HPI}$ for $\gamma$-GT and ALP were observed, respectively. The mean value for ALP peaked at 48 HPI with about 4 folds, and for $\gamma$-GT at 42 HPI with 7 folds, respectively.

Changes in AST and ALT

The AST and ALT were significantly elevated with $p=$ 0.0013 and 0.0005 , respectively. In comparison with baseline values, significant elevation of AST was seen at $18 \mathrm{HPI}, 6 \mathrm{~h}$ earlier than ALT (Fig. 1D and 1E). The mean values of AST peaked at 30 HPI with maximal increment of 37 folds, and for ALT at 24 HPI with 10 folds of the mean at $0 \mathrm{HPI}$, respectively.

\section{Correlation coefficient analysis among indicators \\ AFP significantly and positively correlated to ALP stronger than $\gamma$-GT, but not to AST and ALT. The 4 liver enzymes significantly correlated to each other (Table 2). AST correlated strongly with ALT than with $\gamma$-GT or ALP. However, $\gamma$-GT correlated strongest with ALP.}

\section{Discussion}

Cross-reactivity and similarity in amino acid composition between human and rabbit AFP has been reported (Nishi and Hirai 1972; Pihko et al. 1973). Based on this knowledge, we were able to measure the rabbit AFP using a commercial kit that uses a standardized preparation of horseradish peroxidase (HRP)-

conjugated monoclonal antibody specific for human AFP. We found that this method worked just as fine.

AFP, an oncofoetal antigen, is normally produced by the embryonic yolk sac, the liver and the gastrointestinal tract. Hepatitis is one of few non-neoplastic disorders that cause AFP to increase (Burrell 1992; McCance and Huether 1990; Kumar et al. 2005). Elevation of serum AFP has been reported in patients with HBV infection (HBs antigenemia) (Kitau et al. 1988; Songsivilai et al. 1995). In our experiment, we demonstrated for the first time that a significant increase in serum AFP from 24 HPI indicated that RHDV infection can also induce 
Table 2. The correlation analysis between AFP and serum liver enzymes

\begin{tabular}{|l|l|r|r|r|r|r|}
\hline & Item & \multicolumn{1}{|c|}{ AST } & \multicolumn{1}{c|}{ ALT } & \multicolumn{1}{c|}{$\gamma$-GT } & \multicolumn{1}{c|}{ ALP } & \multicolumn{1}{c|}{ AFP } \\
\hline AST & P. C. C. & 1 & 0.6965 & 0.3936 & 0.3984 & 0.2747 \\
\hline & P. & & $<.0001$ & 0.0213 & 0.0196 & 0.1102 \\
\hline & No. & 35 & 33 & 34 & 34 & 35 \\
\hline ALT & P. C. C. & 0.6965 & 1 & 0.5626 & 0.5168 & 0.3251 \\
\hline & P. & $<.0001$ & & 0.0008 & 0.0025 & 0.0649 \\
\hline & No. & 33 & 33 & 32 & 32 & 33 \\
\hline$\gamma$-GT & P. C. C. & 0.3936 & 0.5626 & 1 & 0.7956 & 0.4247 \\
\hline & P. & 0.0213 & 0.0008 & & $<.0001$ & 0.011 \\
\hline & No. & 34 & 32 & 35 & 35 & 35 \\
\hline ALP & P. C. C. & 0.3984 & 0.5168 & 0.7956 & 1 & 0.7222 \\
\hline & P. & 0.0196 & 0.0025 & $<.0001$ & & $<.0001$ \\
\hline & No. & 34 & 32 & 35 & 35 & 35 \\
\hline AFP & P. C. C. & 0.2747 & 0.3251 & 0.4247 & 0.7222 & 1 \\
\hline & P. & 0.1102 & 0.0649 & 0.011 & $<.0001$ & \\
\hline & No. & 35 & 33 & 35 & 35 & 36 \\
\hline
\end{tabular}

*P. C. C.: Pearson Correlation Coefficients *P.: Probability

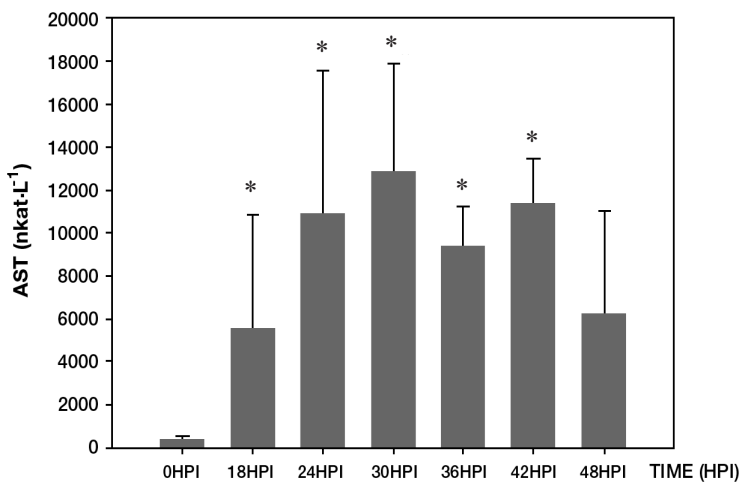

Fig. 1D. Change in AST, $P=0.0013, \mathrm{n}=8$ at 0HPI, 18HPI and $24 \mathrm{HPI}, \mathrm{n}=5$ at $30 \mathrm{HPI}, \mathrm{n}=2$ at $36 \mathrm{HPI}, 42 \mathrm{HPI}$ and $48 \mathrm{HPI}$

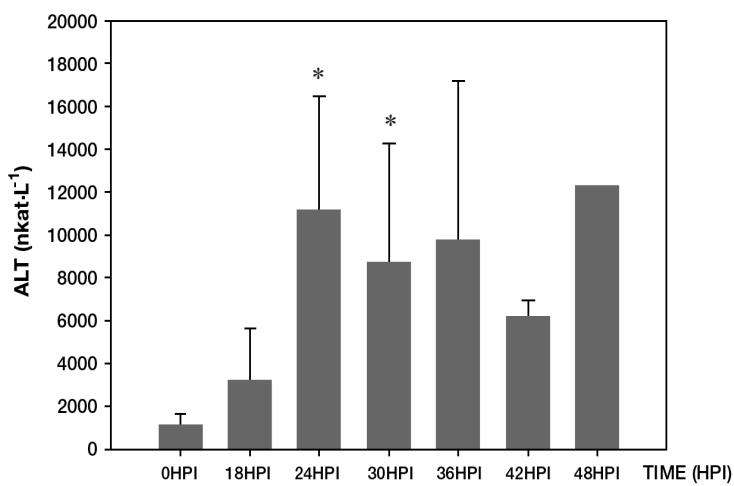

Fig. 1E. Change in ALT, $P=0.0005, \mathrm{n}=8$ at $0 \mathrm{HPI}$ and $18 \mathrm{HPI}$, $\mathrm{n}=7$ at $24 \mathrm{HPI}, \mathrm{n}=5$ at $30 \mathrm{HPI}, \mathrm{n}=2$ at $36 \mathrm{HPI}$ and 42HPI, $\mathrm{n}=148 \mathrm{HPI}$
*No.: Number of observations

AFPelevation. Since the AFP increase significantly and positively correlated with ALP and $\gamma$-GT rather than AST and ALT, it is suggested that elevation of serum AFP was induced by severe hepatic necrosis following the leakage of cytoplasmic enzymes into the systemic circulation. Moreover, with the AFP having a high affinity for oxygen and composed of approximately 80 percent foetal haemoglobulin (Treseler 1995), we speculated that elevation of AFP might play a role in providing the live hepatocytes in necrotic tissues with extra oxygen as a compensatory reaction. Therefore, the more severe the hepatic necrosis became, the higher the AFP became. This can explain why rabbits that died had high AFP values. Thus, measurement of serum AFP might be a useful complementary index of infectivity and prognosis in RHD.

\section{Změny sérového alfa-fetoproteinu u králíků experimentálně infikovaných virem králičí hemoragické nemoci}

Ke studiu změn sérového alfafetoproteinu (AFP) a jeho korelace 
s aktivitou jaterních enzymů při hepatitidě vyvolané virem králičí hemoragické nemoci (RHDV) jsme experimentálně infikovali taiwanským terénním izolátem viru králíky ve věku 15 týdnů. Po inokulaci RHDV se signifikantně zvýšil obsah AFP $(\mathrm{p}=0.0082)$ zároveň se signifikantním zvýšením aktivity sérových enzymů aspartát aminotransferázy (AST), $\gamma$-glutamlytransferázy $(\gamma-$ GT) a alkalické fosfatázy (ALP). Uhynulí králíci měli tendenci $\mathrm{k}$ vyššímu obsahu AFP krátce před uhynutím, s průměrnou hodnotou 4,22 $\pm 1,61 \mathrm{ng} / \mathrm{ml}$ $(\mathrm{n}=6)$. Korelační analýzou jsme prokázali, že AFP signifikantně více koreloval s ALP než s $\gamma-$ GT, ale nevýznamně s AST a ALT. V této práci poprvé prokazujeme zvýšení sérového AFP při infekci RHDV. Tyto výsledky naznačují, že měření sérového AFP může být užitečným doplňujícím indexem pro průkaz infekce RHDV a prognózu onemocnění.

\section{Acknowledgements}

This work was partially supported by a grant-in-aid of ATU project to NCHU by the Ministry of Education, Taiwan.

\section{References}

Burrell LO (Ed.) 1992: Adult nursing in hospital and community settings, E. Norwalk, CT: Appleton \& Lange. $1738 \mathrm{p}$.

Cooke BD, Robinson AJ, Merchant JC, Nardin A, Capucci L 2000: Use of ELISAs in field studies of rabbit haemorrhagic disease (RHD) in Australia. Epidemiol Infect 124: 563-576

Kitau MJ, Grint PC, Heath RB, Chart T 1988: Serum alphafetoprotein levels in subjects infected with hepatitis B virus. J Med Virol 26: 437-442

Kumar V, Abbas AK, Fausto N, Perkins JA 2005: Pathologic basis of disease. $7^{\text {th }}$ ed. Elsevier Inc. 338 p.

Liaw YF, Tai DI, Chen TJ, Chu CM, Huang MJ 1986: Alpha-fetoprotein changes in the course of chronic hepatitis: relation to bridging hepatic necrosis and hepatocellular carcinoma. Liver 6: 133-137

Liu SJ, Xue HP, Pu BQ, Quian NH 1984: A new viral disease in rabbits. Anim Husb Vet Med 16: 253-255

McCance KL, Huether SE 1990: Pathophysiology: Clinical concepts of disease processes. St. Louis, MO: Mosby. $339 \mathrm{p}$.

Nishi S, Hirai H 1972: Purification of human, dog and rabbit alpha-fetoprotein by immunoadsorbents of sepharose coupled with anti-human alpha-fetoprotein. Biochim Biophys Acta 278: 293-298

Ohlinger VF, Haas B, Meyers G, Weiland F, Thiel HJ 1990: Identification and characterization of the virus causing rabbit hemorrhagic disease. J Virol 64: 3331-3336

Park JH, Ochiai K, Itakura C 1992: Detection of rabbit hemorrhagic disease virus particles in the rabbit liver tissues. J Comp Path 107: 329-340

Pihko H, Lindgren J, Ruoslathi E 1973: Rabbit alpha-fetoprotein: immunochemical purification and partial characterization. Immunochemistry 10: 381-385

Shien JH, Shieh HK, Lee LH 1998: Characterization of rabbit hemorrhagic disease field isolates in Taiwan. J Virol Methods 71: 27-33

Songsivilai S, Dharakui T, Senawong S 1995: Hepatitis B- and hepatitis C-associated hepatocellular carcinoma: evaluation of alpha-fetoprotein as a diagnostic marker. Asian Pac J Allergy Immunol 13: 167-171

Treseler KM 1995: Clinical Laboratory and Diagnostic Tests: Significance and nursing implications. $3^{\text {rd }}$. E. Norwalk, CT: Appleton \& Lange. 480 p.

Tunon MJ, Sonia SC, Javier GF, Marcelino A, Francisco J, Javier GG 2003: Rabbit hemorrhagic viral disease: characterization of a new animal model of fulminant liver failure. J Lab Clin Med 141: 272-278

Xu EJ, Chen WX 1989: Viral hemorrhagic disease in rabbits: a review. Vet Res Commun 13: 205-212 